\title{
Effects of two peroxide enzymatic denture cleaners on Candida albicans biofilms and denture surface
}

\author{
Ying $\mathrm{Han}^{1+}$, Xiaodan $\mathrm{Liu}^{2+}$ and Yu Cai ${ }^{3,4^{*}}$
}

\begin{abstract}
Objective: To compare the antifungal action of two commercially available denture cleaning agents to that of standard clinical solutions, and determine their effects on the polymethyl methacrylate (PMMA) acrylic resin denture surface.

Methods: Candida albicans growth was analyzed by colony forming assay, and the methyl thiazolyl tetrazolium (MTT) assay was used to evaluate biofilm formation and cell adhesion. The morphology and roughness of PMMA acrylic resin surface was measured by scanning electron microscopy (SEM) images and stylus method.

Results: Clene ${ }^{\oplus}$, Polident ${ }^{\oplus}$ and $3 \% \mathrm{NaHCO}_{3}$ solutions showed significantly greater antifungal effects in terms of both inhibiting growth and biofilm formation. In addition, Clene ${ }^{\circledast}$ solution prevented adhesion of C. albicans on cell culture plates compared to filter-sterile tap water, whereas other reagents did not have an inhibitory effect. One-month immersion in the different cleaning reagents significantly inhibited fungal adhesion on the PMMA surface Clene ${ }^{\circledast}$, Polident ${ }^{\oplus}$ and $3 \% \mathrm{NaHCO}_{3}$ showed greater effect compared to PBS and filter-sterile tap water. Finally, none of the cleansing agents significantly affected the morphology and roughness of the PMMA surface.

Conclusion: Clene ${ }^{\oplus}$, Polident ${ }^{\oplus}$ and $3 \% \mathrm{NaHCO}_{3}$ solutions can inhibit C. albicans growth and biofilm formation to some extent on cell culture plates, and significantly inhibit fungal adhesion on the PMMA surface without affecting surface morphology and roughness.
\end{abstract}

\section{Introduction}

Denture-induced stomatitis (DS) is caused by the opportunistic yeast Candida spp., and is characterized by white pseudomembranous lesions covering large areas of the oral mucosa such as tongue or palate [1]. C. albicans

\footnotetext{
* Correspondence: jessonjesson@hotmail.com

${ }^{\dagger}$ Ying Han and Xiaodan Liu contributed equally to this work.

${ }^{3}$ Department of Periodontology, Peking University School and Hospital of Stomatology \& National Clinical Research Center for Oral Diseases \& National Engineering Laboratory for Digital and Material Technology of Stomatology \& Beijing Key Laboratory of Digital Stomatology, 22 Zhongguancun South Avenue, Haidian District, Beijing 100081, PR China

${ }^{4}$ Central Laboratory, Peking University School and Hospital of Stomatology \& National Clinical Research Center for Oral Diseases \& National Engineering Laboratory for Digital and Material Technology of Stomatology \& Beijing Key Laboratory of Digital Stomatology, 22 Zhongguancun South Avenue, Haidian District, Beijing 100081, PR China

Full list of author information is available at the end of the article
}

is one of the major causative organism in Candida spp., primarily due to its ability to rapidly adhere to, and form resilient drug-resistant biofilms on the soft and hard oral cavity tissues [2]. C. albicans is a dimorphic yeast that can exist in both hyphal and yeast forms depending on the environment [3]. In addition, C. albicans is also the most common Candida species found in the healthy human oral mucosa, and causes candidiasis due to its adherence properties and pathogenicity [4]. The transition of resident Candida from the commensal to pathogenic form depends on various local and systemic factors.

Poorly fitted dentures occlude the oral mucosa and inhibit salivary flow, leading to Candida overgrowth $[3,5]$. In addition, the denture base materials are an ideal surface for plaque and calculus formation, which further promote C. albicans adherence and growth. Compared

(c) The Author(s). 2020 Open Access This article is licensed under a Creative Commons Attribution 4.0 International License, which permits use, sharing, adaptation, distribution and reproduction in any medium or format, as long as you give appropriate credit to the original author(s) and the source, provide a link to the Creative Commons licence, and indicate if changes were made. The images or other third party material in this article are included in the article's Creative Commons licence, unless indicated otherwise in a credit line to the material. If material is not included in the article's Creative Commons licence and your intended use is not permitted by statutory regulation or exceeds the permitted use, you will need to obtain permission directly from the copyright holder. To view a copy of this licence, visit http://creativecommons.org/licenses/by/4.0/. The Creative Commons Public Domain Dedication waiver (http://creativecommons.org/publicdomain/zero/1.0/) applies to the data made available in this article, unless otherwise stated in a credit line to the data. 
to other dental materials, polymethyl methacrylate (PMMA) acrylic resin is more frequently colonized by this yeast [6], and usually requires periodic cleaning by chemicals [7] like alkaline peroxides, alkaline hypochlorite, acids, disinfectant and enzymes [8] to inhibit biofilm growth. The most commonly-used denture cleansers are the immersion type which clean as well as decontaminate the prostheses [9]. Polident ${ }^{\circ}$ is a peroxide- and enzyme-based cleaning agent with considerable antifungal effects $[9,10]$. Clene ${ }^{\circ}$ is similar to Polident ${ }^{\circ}$ in composition and can effectively inhibit Candida growth. The aim of this study was to compare the above denture cleansers in terms of their effects on C. albicans adherence and biofilm formation, and on the mechanical characteristics of PMMA acrylic resin.

\section{Materials and methods}

\section{Preparation of test solutions}

Solutions of Clene ${ }^{\circ}$ (Bitec global group, Japan), Polident ${ }^{\circ}$ (PTI Royston LLC, USA), 3\% sodium bicarbonate $\left(\mathrm{NaHCO}_{3}\right.$, Tianjin Lisheng Pharmaceutical Co. LTD, China) and phosphate-buffer Saline (PBS, Gibco Invitrogen $^{\mathrm{Tm}}$, USA) were prepared at the recommended concentrations by adding one tablet or sachet in $200 \mathrm{ml}$ filter-sterile tap water at room temperature (RT).

\section{C. albicans culture}

C. albicans strain ATCC 90028 (School of Stomatology, Peking University, China) was cultured in Roswell Park Memorial Institute (RPMI) 1640 medium (HyClone, Logan, USA) at $37^{\circ} \mathrm{C}$ for $48 \mathrm{~h}$, and the primary culture was passaged and grown for another $24 \mathrm{~h}$. The yeast cells were harvested by centrifuging the broth cultures (Labofuge $400 \mathrm{R}$, Function-line, Heraeus Instruments, Bensheim, Germany) at $3000 \mathrm{rpm}$ for $10 \mathrm{~min}$. The cell pellets were washed twice with PBS, and re-suspended at the final density of $10^{5} \mathrm{CFU} / \mathrm{ml}$ for evaluating antifungal and anti-adhesion effects on the PMMA acrylic resin base [11], and $10^{6} \mathrm{CFU} / \mathrm{ml}$ for evaluating anti-biofilm and anti-adhesion effects on cell culture plates [12].

\section{Evaluation of antifungal effects}

One milliliter of the $C$. albicans suspension was dispensed in five separate sterile test tubes each, and respectively treated with $9 \mathrm{ml} \mathrm{Clene}{ }^{\circ}$, Polident ${ }^{\circ}$, 3\% $\mathrm{NaHCO}_{3}, \mathrm{PBS}$ and filter-sterile tap water for 30, 60 and $120 \mathrm{~min}$. The tubes were sonicated at $7-\mathrm{W}$ for 30s [13] and vortexed at the stipulated time points, and $1 \mathrm{ml}$ aliquots were plated on Sabourad dextrose agar (SDA, Antobio Co., China) using a spiral plater (Spiral system; Interscience, Saint-Nom-La-Breeches, France). The plates were incubated at $37^{\circ} \mathrm{C}$ for $24 \mathrm{~h}$, and the number of colonies were counted. Three biological replicates with three technical replicates each were tested for every condition.

\section{Evaluation of anti-biofilm effects}

One hundred microliter aliquots of $C$. albicans suspension $\left(10^{6} \mathrm{CFU} / \mathrm{ml}\right)$ were seeded in pre-sterilized 96-well cell culture plates (Corning Co., USA), and incubated for $90 \mathrm{~min}$ (adhesion phase) at $37^{\circ} \mathrm{C}$ in an orbital shaker at $75 \mathrm{rpm}$ [14]. The non-adherent cells were removed by gently washing thrice with PBS, and $100 \mu$ RPMI-1640 was added to each well. After incubating for another 24 $\mathrm{h}$, the medium was removed and the wells were washed twice with PBS, followed by addition of $100 \mu \mathrm{l}$ each of fresh RPMI and a cleansing solution. The cells were incubated for $48 \mathrm{~h}$ [15] and the non-adherent cells were removed. The resultant biofilm was quantified using methyl thiazolyl tetrazolium (MTT) assay (Sigma Chemical Co., USA). Briefly, $20 \mu \mathrm{l} \mathrm{MTT} \mathrm{(5} \mathrm{mg} / \mathrm{ml}$ in PBS) was added to each well, and incubated for $4 \mathrm{~h}$ in the dark. The supernatant was aspirated and $100 \mu \mathrm{l}$ dimethylsulfoxide (DMSO, Sigma Chemical Co., USA) was added to each well, and the optical density (OD) was measured at $490 \mathrm{~nm}$ after 30 mins. The experiment was repeated at least three times. Each experiment was set up in triplicate with three replicates per sample.

\section{Evaluation of anti-adhesion effects}

C. albicans suspension $\left(10^{6} \mathrm{CFU} / \mathrm{ml}\right)$ was seeded in 96 well cell culture plate, and incubated with $200 \mu \mathrm{l}$ of the different solutions for $90 \mathrm{mins}$ (adhesion phase) at $37{ }^{\circ} \mathrm{C}$ in an orbital shaker at $75 \mathrm{rpm}$. After gently washing thrice with PBS to remove the non-adherent cells, the biofilm was quantified by MTT assay as described above. All experiments were performed in duplication of three independent sessions.

\section{Evaluation of microbial adhesion on PMMA base}

Forty-five circular heat-cured PMMA resin Vertex Rapid Simplified (Vertex-Dental B.V.: Zeist, Netherlands) plates (diameter $10 \mathrm{~mm}$ and thickness $2 \mathrm{~mm}$ ) were fabricated, and sanded with 360, 400 and 600-grit abrasive papers (Carbimet, Buehler, Lake Bluff, IL, USA) under refrigeration to remove the scratches formed during grinding. After buffing with a polishing cloth and $1 \mu \mathrm{m}$ diamond suspension (Metadi diamond suspension, Buehler, Lake Bluff, IL, USA), the disks were sonicated in filter-sterile tap water in a $900-\mathrm{W}$ microwave oven for 3 mins at $360-\mathrm{W}$, and for another 3 mins at $810-\mathrm{W}$ after a 4 mins interval [14]. The disks were then washed with a high-pressure water spray to eliminate any surface contaminants, and finally sterilized with $95 \%$ ethanol. The prepared disks were first immersed in artificial saliva [15] $(0.02 \%$ calcium chloride, $0.11 \%$ sodium phosphate, $0.17 \%$ sodium bicarbonate and $0.2 \%$ sodium 
azide) for $24 \mathrm{~h}$ at $37^{\circ} \mathrm{C}$, and then transferred to $40 \mathrm{ml}$ of the respective cleansing solution/filter-sterile tap water. After a 4-week incubation with daily change of solution, the disks were taken out, washed with $\mathrm{PBS}$, and immersed in filter-sterile tap water for $24 \mathrm{~h}$ at $37^{\circ} \mathrm{C}$ [9]. To measure C. albicans adhesion, $20 \mathrm{ml}$ C. albicans suspension $\left(10^{5} \mathrm{CFU} / \mathrm{ml}\right)$ was added to each tube and incubated for 90 mins. After washing with PBS to remove non-adherent cells, the disks were transferred to polypropylene tubes containing $3 \mathrm{ml}$ sterile $\mathrm{PBS}$ each, and sonicated at $7-\mathrm{W}$ for 30 s [13]. The resulting single-cell suspension was plated on SDA, cultured at $37^{\circ} \mathrm{C}$ for 24 $\mathrm{h}$, and the number of colonies were counted by using a spiral plater. All experiments were performed with three independent sections on three independent sessions.

\section{Evaluation of the surface morphology and roughness of PMMA base}

Forty-five circular heat-cured PMMA base disks were fabricated as described above, immersed in artificial saliva for $24 \mathrm{~h}$ at $37^{\circ} \mathrm{C}$, and then in $40 \mathrm{ml}$ of the respective cleansing solution/ filter-sterile tap water for $8 \mathrm{~h}$. The disks were removed and air dried, and the surface morphology micropatterns were analyzed by scanning electron microscopy (SEM). The roughness of the surface was measured in 3 different areas by the stylus method (Surftest SJ-400, Mitutoyo Industry, Japan), and the mean roughness was calculated. All experiments were performed with three independent sections on three independent sessions.

\section{Statistical analysis}

All results are expressed as the mean \pm standard deviation (SD). Data were analyzed using SPSS 13.0 software (IBM, Chicago, USA), and compared using one-way analysis of variance (ANOVA) followed by pair-wise Bonferroni test. $P<0.05$ was considered statistically significant.

\section{Results}

\section{Growth of C. albicans}

All denture cleansers decreased the growth of C. albicans, evaluated in terms of the number of colonies, in a time-dependent manner compared to filter-sterile tap water (Fig. 1 and Table 1). The inhibitory effects of Clene $^{\circ}$ and Polident ${ }^{\circ}$ were significantly higher compared to that of $3 \% \mathrm{NaHCO}_{3}(P<0.05)$ and PBS $(P<0.05)$, while no significant differences were observed between the two commercial cleansers, or between $3 \% \mathrm{NaHCO}_{3}$ and PBS. As shown in the Table 1, Clene ${ }^{\circ}$ and Polident ${ }^{\circ}$ decreased fungal growth by approximately 98 and 100\% respectively, while $3 \% \mathrm{NaHCO}_{3}$ and $\mathrm{PBS}$ achieved only 67.54 and $51.30 \%$ reduction.

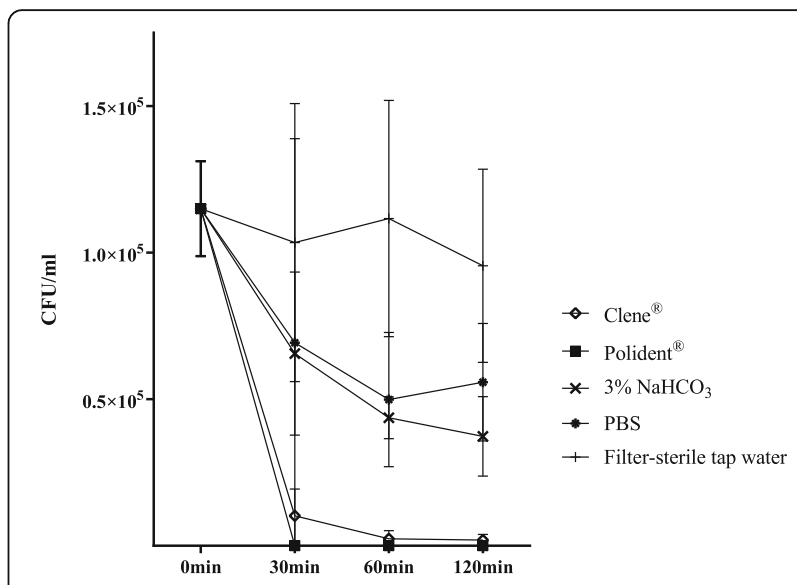

Fig. 1 The mean \pm SD numbers of colony-forming units (CFUs) after 30,60 and 120 mins of incubation with the different cleansers

\section{Biofilm formation}

Compared to filter-sterile tap water $\left(\mathrm{OD}_{490}=0.09 \pm\right.$ 0.02), all reagents inhibited C. albicans biofilm formation to some extent. However, no significant differences were detected among Clene ${ }^{\circ}\left(\mathrm{OD}_{490}=0.06 \pm 0.00\right)$, Polident ${ }^{\circ}$ $\left(\mathrm{OD}_{490}=0.05 \pm 0.00\right), 3 \% \mathrm{NaHCO}_{3}\left(\mathrm{OD}_{490}=0.06 \pm 0.01\right)$, and PBS $\left(\mathrm{OD}_{490}=0.06 \pm 0.01\right)$ (Fig. 2).

\section{C. albicans adhesion on tissue culture-treated polystyrene substrate}

Clene ${ }^{\circ}\left(\mathrm{OD}_{490}=0.11 \pm 0.03\right)$ prevented adhesion of $C$. albicans compared to filter-sterile tap water $\left(\mathrm{OD}_{490}=\right.$ $0.17 \pm 0.05)$. Interestingly, Polident ${ }^{\circ}\left(\mathrm{OD}_{490}=0.25 \pm 0.12\right)$ promoted adhesion of $C$. albicans, resulting in dense cellular layers compared to that seen in the Clene ${ }^{\circ}, 3 \%$ $\mathrm{NaHCO}_{3} \quad\left(\mathrm{OD}_{490}=0.12 \pm 0.02\right), \quad \mathrm{PBS} \quad\left(\mathrm{OD}_{490}=0.14 \pm\right.$ $0.03)$ and filter-sterile tap water $(P<0.05)$ groups. Compared to $\mathrm{PBS}$ and filter-sterile tap water group, 3\% $\mathrm{NaHCO}_{3}$ did not significantly inhibit the adhesion of $C$. albicans. Furthermore, no significant differences were seen between $\mathrm{Clene}^{\circ}$ and 3\% $\mathrm{NaHCO}_{3}$ (Fig. 3).

\section{C. albicans adhesion on PMMA base}

Compared to PBS and filter-sterile tap water, Clene ${ }^{\circ}$, Polident ${ }^{\circ}$ and $3 \% \mathrm{NaHCO}_{3}$ significantly reduced C. albicans adhesion on the PMMA base surface $(P<0.05)$ (Fig. 4).

\section{Surface morphology and roughness of PMMA base}

The surface roughness of the PMMA base disks was not significantly affected even after overnight immersion in the different cleansing reagents (Table 2), and no significant differences were observed between the different groups on PMMA base surface morphology (Fig. 5). 
Table 1 Mean and standard deviation (SD) in number $\left(10^{5} \mathrm{CFU} / \mathrm{ml}\right)$ of Candida spp. over the evaluation periods of 30, 60 and 120 $\min (n=9)$

\begin{tabular}{|c|c|c|c|c|c|}
\hline \multirow[t]{2}{*}{ Solutions } & \multirow[b]{2}{*}{0 min(all) } & \multicolumn{3}{|c|}{ Mean (SD) $\left(10^{5} \mathrm{CFU} / \mathrm{ml}\right)$} & \multirow{2}{*}{$\begin{array}{l}\text { Percent (\%) } \\
(0 \mathrm{~min}-120 \mathrm{~min}) / 0 \mathrm{~min}\end{array}$} \\
\hline & & $30 \mathrm{~min}$ & $60 \mathrm{~min}$ & $120 \mathrm{~min}$ & \\
\hline Clene $^{\oplus}$ & $1.15(0.16)$ & $0.10(0.09)$ & $0.02(0.03)$ & $0.02(0.02)$ & 98.27 \\
\hline Polident ${ }^{\oplus}$ & & $0.00(0.00)$ & $0.00(0.00)$ & $0.00(0.00)$ & 100 \\
\hline $3 \% \mathrm{NaHCO}_{3}$ & & $0.66(0.28)$ & $0.44(0.07)$ & $0.37(0.14)$ & 67.54 \\
\hline PBS & & $0.69(0.70)$ & $0.50(0.23)$ & $0.56(0.20)$ & 51.30 \\
\hline Filter-sterile tap water & & $1.03(0.47)$ & $1.12(0.40)$ & $0.96(0.33)$ & 16.52 \\
\hline
\end{tabular}

\section{Discussion}

Denture stomatitis (DS) is a frequent complication in patients with dentures, especially in the elderly with limited salivary flow. Poorly fitted dentures occlude the oral mucosa and inhibit salivary flow, leading to Candida albicans overgrowth [3, 5]. Furthermore, accumulation of plaque and calculus on the denture base materials encourage the adherence and growth of $C$. albicans. Compared to other dental materials, PMMA acrylic resin is more frequently colonized by this yeast [6], and the resulting biofilm has to be removed periodically by chemical and physical methods [7]. Several chemical denture cleansers have been formulated that can control and even eradicate fungal infection from the denture surface [8].

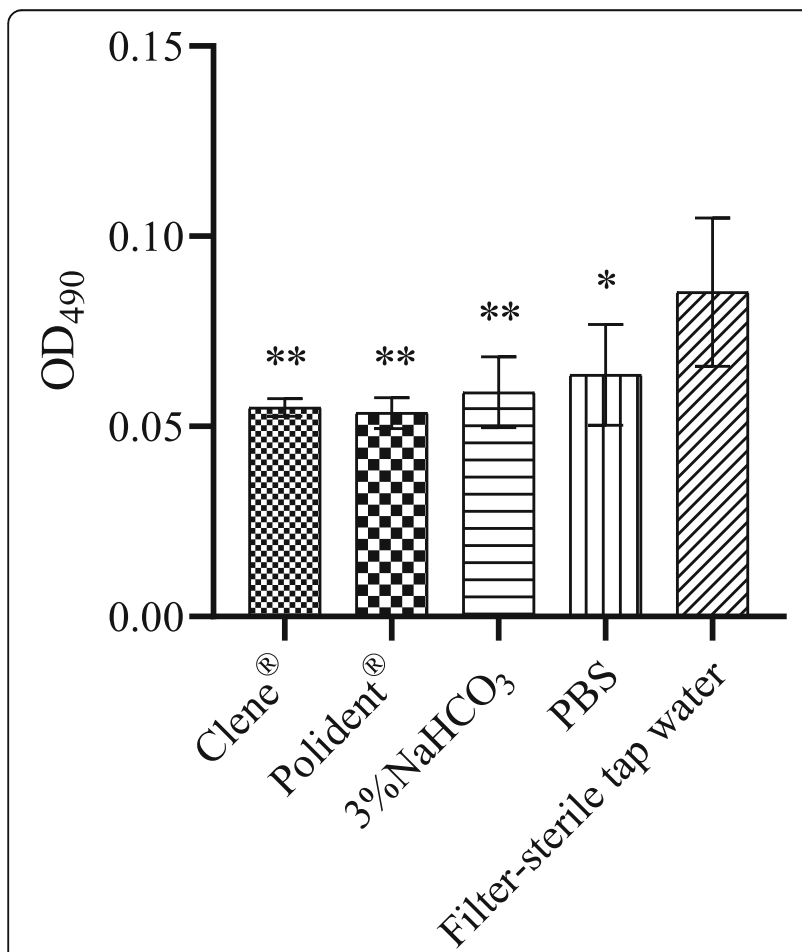

Fig. 2 ODs indicating biofilm formation after different treatments. The data represent the mean \pm SD from three independent experiments of each sample. ${ }^{*} P<0.05,{ }^{* *} P<0.01$ compared with the filter-sterile tap water group
Polident $^{\oplus}$ is a commercial chemical denture cleanser that can significantly inhibit the proliferation of C. albicans $[9,10,15,16]$. In addition, studies also show that sodium bicarbonate can effectively inhibit and disperse yeast biofilms $[17,18]$. Clene ${ }^{\bullet}$ has a similar composition as Polident ${ }^{\oplus}$ but its effect on $C$. albicans growth and the PMMA acrylic resin denture surface is not well known. Compared to $3 \% \mathrm{NaHCO}_{3}$, we found both Clene ${ }^{\bullet}$ and Polident $^{\oplus}$ significantly inhibited the growth of $C$. albicans in a time-dependent manner. Ufuk et al. also showed that Polident ${ }^{\odot}$ reduced 26 and $50 \%$ of the plaques within 30 and 60 mins of immersion respectively [9], while Ghalichebaf et al. reported $<30 \%$ plaque clearance in $15 \mathrm{~min}$ [10]. However, Lucena-Ferreira

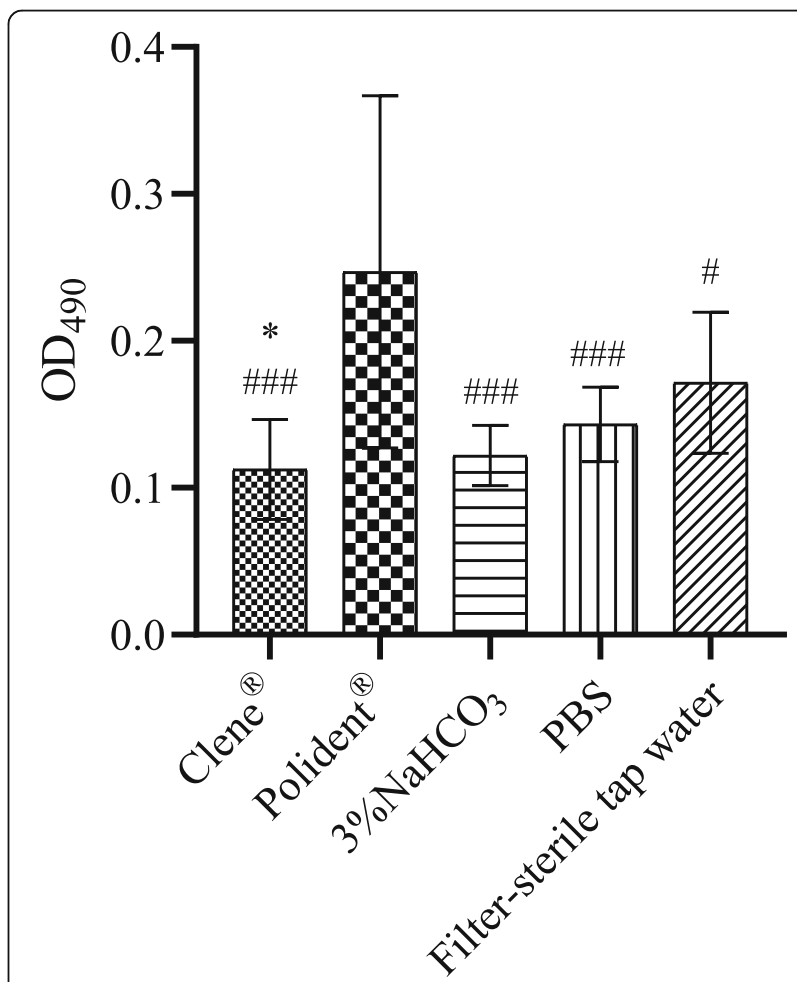

Fig. 3 ODs indicating cell adhesion after different treatments. The data represent the mean \pm SD from three independent experiments of each sample. ${ }^{*} P<0.05$ compared with the filter-sterile tap water

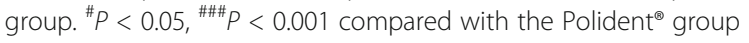




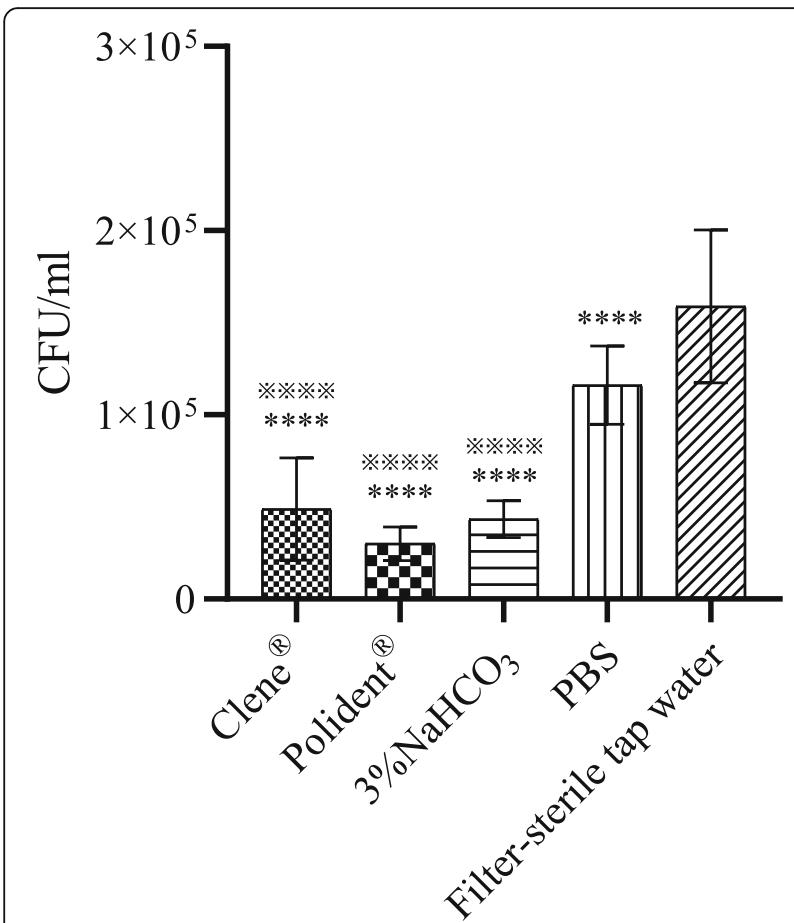

Fig. 4 C. albicans colony counts after different treatments. The data show the mean \pm SD from three independent experiments of each sample. ${ }^{* * *} P<0.0001$ compared with the filter-sterile tap water group; $* * * \aleph_{p}<0.0001$ compared with the PBS group

et al. observed no difference in Candida spp. growth after daily immersion in Polident ${ }^{\circ}$ for 3 min following nocturnal brushing [13]. In addition, some studies have showed an increase in Candida spp. growth after denture cleanser use, which might be relevant to the development of DS [19].

Biofilm formation is an important factor in the pathogenesis of DS, and consists of a complex mixture of fungi, bacteria and desquamated epithelial cells that protects the oral microbiota [9]. The adherence of C. albicans to the denture surfaces is the first step to successful colonization and the subsequent pathogenesis [12, 20]. In this study, we found that all denture cleansers prevented biofilm formation, and similar inhibitory effects were seen with Clene ${ }^{\circ}$, Polident ${ }^{\circ}$ and $3 \% \mathrm{NaHCO}_{3}$ solutions. Freitas-Fernandes et al. also found that Polident ${ }^{\circ}$

Table 2 Mean and standard deviation (SD) for the Surface Roughness $(\mathrm{Ra}, \mu \mathrm{m})$ of the PMMA Base for solutions $(n=9)$

\begin{tabular}{ll}
\hline Solutions & Mean (SD) \\
\hline Clene $^{\circledR}$ & $0.12(0.03)$ \\
Polident $^{\circledR}$ & $0.12(0.04)$ \\
$3 \% \mathrm{NaHCO}_{3}$ & $0.12(0.04)$ \\
$\mathrm{PBS}$ & $0.13(0.03)$ \\
Filter-sterile tap water & $0.13(0.03)$
\end{tabular}

Data indicate no statistically significant difference $(P>0.05)$

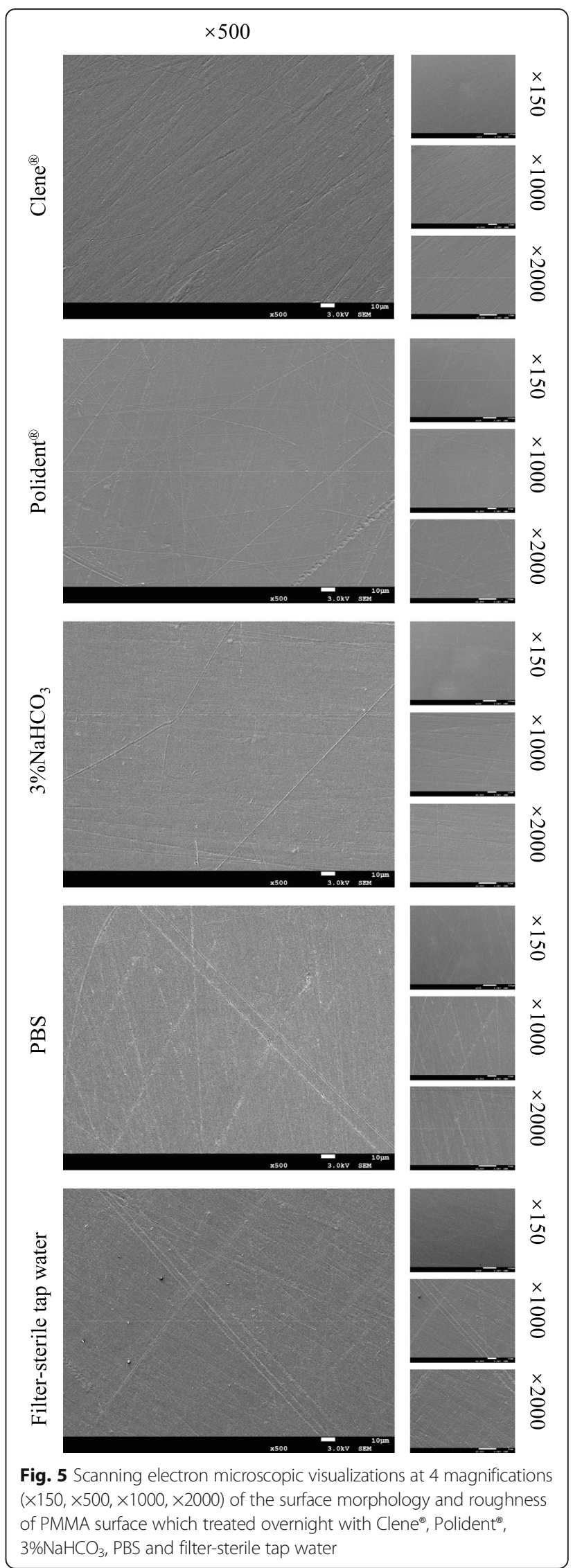


inhibited biofilm formation [16]. Clene ${ }^{\bullet}$ showed good anti-adhesion activity in the early stages, whereas Polident $^{\circ}$ promoted the adhesion of $C$. albicans and increased the density of cellular layers on the polystyrene substrate. No significant differences were seen between $3 \% \mathrm{NaHCO}_{3}, \mathrm{PBS}$ and filter-sterile tap water. Furthermore, $C$. albicans adhesion regressed significantly on PMMA disks immersed for 4 weeks in the different reagents, with Clene ${ }^{\circ}$, Polident ${ }^{\circ}$ and $3 \% \mathrm{NaHCO}_{3}$ showing higher efficacy compared to PBS and filter-sterile tap water. Hayran et al. also found that Polident tablets significantly inhibited the proliferation of $C$. albicans on all denture resins. Consistent with previous studies [21, 22], none of the reagents significantly affected the surface morphology and roughness of the PMMA acrylic resin. Furthermore, Polident ${ }^{\circ}$ in fact reduced the roughness compared to the cleanser/water mixture [22].

Polident ${ }^{\circ}$ is a mixture of peroxide-based compounds (including potassium kaluic acid and sodium carbonate peroxide) and proteolytic enzymes [23]. The alkaline peroxide-based denture cleansers effervesce in water and mechanically disperse the microbial biofilms. In addition, dissolution of hydrogen peroxide releases oxygen that kills the microbial cells via oxidative damage, whereas the proteolytic enzymes break down the biofilm proteins [24]. Clene ${ }^{\circ}$ is a mixture of yeast-decomposing, starchdegrading, proteolytic, lipolytic and fibrolytic enzymes, and a peroxide-based compound. There were some minor variations between the efficacy of $\mathrm{Clene}^{\circ}$ and Polident $^{\circ}$, which may be attributed to their different composition. The unique composition of $\mathrm{Clene}^{\bullet}$ may translate to greater biocompatibility as well, which ought to be explored in future studies.

\section{Conclusion}

Both Clene ${ }^{\circ}$ and Polident ${ }^{\circ}$ inhibited fungal adhesion and growth on PMMA acrylic resin base without affecting the surface morphology and roughness. Our findings will have to be validated on DS patients, to observe the therapeutic effect of these reagents in patients.

\section{Acknowledgements}

Grateful acknowledgement is made to Dr. Peng Zhang and Ms. Qian Zhang for their academic supervision, and we are also grateful to Mr. Di Wang for his personal support.

\section{Authors' contributions}

Y.H. participated in data collection of microbial adhesion and surface roughness of acrylic resin denture base. XD.L. completed the rest of the experiment, data entry and preliminary data analyses, reviewed the literature, and drafted and edited the manuscript. Y.C. participated in study protocol design, supplied samples, final approval of manuscript. All authors read and approved the final manuscript.

\section{Funding}

Program for New Clinical Techniques and Therapies of Peking University School and Hospital of Stomatology (PKUSSNCT-16A07), and Program of Peking University School and Hospital of Stomatology (PKUSS20170103).

\section{Availability of data and materials}

The datasets used and/or analyzed during the current study are available from the corresponding author on reasonable request.

Ethics approval and consent to participate

Not applicable.

Consent for publication

Not applicable.

\section{Competing interests}

The authors declare that they have no competing interests.

\section{Author details}

'Department of Oral Medicine, Peking University School and Hospital of Stomatology \& National Clinical Research Center for Oral Diseases \& National Engineering Laboratory for Digital and Material Technology of Stomatology \& Beijing Key Laboratory of Digital Stomatology, Beijing, China. ${ }^{2}$ Department of Stomatology, Peking University Third Hospital, Beijing, China. ${ }^{3}$ Department of Periodontology, Peking University School and Hospital of Stomatology \& National Clinical Research Center for Oral Diseases \& National Engineering Laboratory for Digital and Material Technology of Stomatology \& Beijing Key Laboratory of Digital Stomatology, 22 Zhongguancun South Avenue, Haidian District, Beijing 100081, PR China. ${ }^{4}$ Central Laboratory, Peking University School and Hospital of Stomatology \& National Clinical Research Center for Oral Diseases \& National Engineering Laboratory for Digital and Material Technology of Stomatology \& Beijing Key Laboratory of Digital Stomatology, 22 Zhongguancun South Avenue, Haidian District, Beijing 100081, PR China.

Received: 26 February 2020 Accepted: 25 June 2020

Published online: 08 July 2020

\section{References}

1. Ramage G, Zalewska A, Cameron DA, Sherry L, Murray C, Finnegan MB, Loewy $Z$ G, Jagger DC. A comparative in vitro study of two denture cleaning techniques as an effective strategy for inhibiting Candida albicans biofilms on denture surfaces and reducing inflammation. J Prosthodont. 2012;21(7): 516-22.

2. Coco BJ, Bagg J, Cross LJ, Jose A, Cross J, Ramage G. Mixed Candida albicans and Candida glabrata populations associated with the pathogenesis of denture stomatitis. Oral Microbiol Immunol. 2008;23(5):37783.

3. Farah CS, Lynch N, McCullough MJ. Oral fungal infections: an update for the general practitioner. Aust Dent J. 2010;55(Suppl 1):48-54.

4. Zegarelli DJ. Fungal infections of the oral cavity. Otolaryngol Clin N Am. 1993;26(6):1069-89.

5. Arendorf TM, Walker DM. Denture stomatitis: a review. J Oral Rehabil. 1987; 14(3):217-27.

6. Li L, Finnegan MB, Ozkan S, Kim Y, Lillehoj PB, Ho CM, Lux R, Mito R, Loewy Z, Shi W. In vitro study of biofilm formation and effectiveness of antimicrobial treatment on various dental material surfaces. Mol Oral Microbiol. 2010;25(6):384-90

7. Baillie GS, Douglas LJ. Effect of growth rate on resistance of Candida albicans biofilms to antifungal agents. Antimicrob Agents Chemother. 1998; 42(8):1900-5.

8. Al-Huraishi H, Moran J, Jagger R, MacDonald E. Evaluation of stain removal and inhibition properties of eight denture cleansers: an in vitro study. Gerodontology. 2013;30(1):10-7.

9. Iseri U, Uludamar A, Ozkan YK. Effectiveness of different cleaning agents on the adherence of Candida albicans to acrylic denture base resin. Gerodontology. 2011;28(4):271-6.

10. Ghalichebaf M, Graser GN, Zander HA. The efficacy of denture-cleansing agents - journal of prosthetic dentistry. J Prosthet Dent. 1982;48(5):515-20.

11. Zaragoza O, Mesa-Arango AC, Gomez-Lopez A, Bernal-Martinez L, Rodriguez-Tudela JL, Cuenca-Estrella M. Process analysis of variables for standardization of antifungal susceptibility testing of nonfermentative yeasts. Antimicrob Agents Chemother. 2011;55(4):1563-70.

12. Nakamoto K, Tamamoto M, Hamada T: Evaluation of denture cleansers with and without enzymes against Candida albicans. J Prosthet Dent. 1991;66(6): $792-5$. 
13. Lucena-Ferreira SC, Cavalcanti IM, Cury AA. Efficacy of denture cleansers in reducing microbial counts from removable partial dentures: a short-term clinical evaluation. Braz Dent J. 2013;24(4):353-6.

14. Pellizzaro D, Polyzois G, Machado AL, Giampaolo ET, Sanita PV, Vergani CE: Effectiveness of mechanical brushing with different denture cleansing agents in reducing in vitro Candida albicans biofilm viability. Braz Dent J. 2012;23(5):547-54.

15. Hayran Y, Sarikaya I, Aydin A, Tekin YH: Determination of the effective anticandidal concentration of denture cleanser tablets on some denture base resins. Journal of applied oral science: revista FOB. 2018;26:e20170077.

16. Freitas-Fernandes FS, Cavalcanti YW, Ricomini Filho AP, Silva WJ, Del Bel Cury AA, Bertolini MM: Effect of daily use of an enzymatic denture cleanser on Candida albicans biofilms formed on polyamide and poly(methyl methacrylate) resins: an in vitro study. J Prosthet Dent. 2014;112(6):1349-55.

17. Gawande PV, LoVetri K, Yakandawala N, Romeo T, Zhanel GG, Cvitkovitch DG, Madhyastha S: Antibiofilm activity of sodium bicarbonate, sodium metaperiodate and SDS combination against dental unit waterlineassociated bacteria and yeast. J Appl Microbiol. 2008;105(4):986-92.

18. Sousa FA, Paradella TC, Koga-Ito CY, Jorge AO: Effect of sodium bicarbonate on Candida albicans adherence to thermally activated acrylic resin. Braz Oral Res. 2009;23(4):381-5.

19. Figueiral MH, Azul A, Pinto E, Fonseca PA, Branco FM, Scully C. Denturerelated stomatitis: identification of aetiological and predisposing factors - a large cohort. J Oral Rehabil. 2010;34(6):448-55.

20. Samaranayake LP, Mccourtie J, Macfarlane TW: Factors affecting the in-vitro adherence of Candida albicans to acrylic surfaces. Arch Oral Biol. 1980;25(8): $611-5$.

21. Felipucci DN, Davi LR, Paranhos HF, Bezzon OL, Silva RF, Pagnano VO. Effect of different cleansers on the surface of removable partial denture. Braz Dent J. 2011;22(5):392-7.

22. Rodrigues Garcia RC, Joane Augusto de S, Jr., Rached RN, Del Bel Cury AA: Effect of denture cleansers on the surface roughness and hardness of a microwave-cured acrylic resin and dental alloys. J Prosthodont. 2004;13(3): 173-8.

23. Yuan SP, Lin H, Pan S, Lou LL, Xu YX. Effect of Polident denture cleansers on the properties of heat-polymerized denture base acrylic resin. Beijing Da Xue Xue Bao. 2012:44(6):946-9.

24. Budtz-Jorgensen E. Materials and methods for cleaning dentures. J Prosthet Dent. 1979:42(6):619-23.

\section{Publisher's Note}

Springer Nature remains neutral with regard to jurisdictional claims in published maps and institutional affiliations.

Ready to submit your research? Choose BMC and benefit from:

- fast, convenient online submission

- thorough peer review by experienced researchers in your field

- rapid publication on acceptance

- support for research data, including large and complex data types

- gold Open Access which fosters wider collaboration and increased citations

- maximum visibility for your research: over $100 \mathrm{M}$ website views per year

At $\mathrm{BMC}$, research is always in progress.

Learn more biomedcentral.com/submissions 